\title{
Selected philosophical and cultural problems associated with World Music and Sound Art - an inquiry about ideological relationships
}

\author{
Paulina TenderA
}

\begin{abstract}
The intention of this article is provide a preliminary comparison of two areas of music which are frequently associated with one another - in pieces of opinion journalism, in reviews, and sometimes on the stage however, contrary to superficial intuitions, they differ from each other considerably - not only in their cultural sources and philosophical premise but also in the final sound-related and music-related result, which may be heard during concerts. Both musical trends are a result of ideological transformations within the world of music, but the reasons for which they arose are extremely different. Let this article serve the purpose of posing questions and making an attempt at outlining the differences between World Music and Sound Art.
\end{abstract}

Keywords: World Music, Sound Art, American Culture, philosophy of music, transculturalism

Paulina Tendera PhD in Philosophy (Jagiellonian University, Krakow), philosopher of art, interested in ontology of painting, transcultural art theory, philosophy of Plato. She is the author of Od filozofii światta do sztuki światta (From Philosophy of Light to The Art of Light, Krakow 2014), and is currently working on two other books with the Polish painter prof. Paweł Taranczewski: On Painting and On colour. She is a member of the Polish Philosophical Society.

More info: google.com/+PaulinaTendera.

E-MAIL: paulina.tendera@gmail.com 
Let us begin by stating a fact: despite many centuries of attempts at acquiring an autonomy for art (the so-called freedom of art), the autonomism of the value of music is not the ideal and the purpose of any kind of musical output and of each artist. There are many areas of such activities in which music is subordinated to cultural, religious or political content. Such is the case only to a minimal extent by way of duress (many readers will supposedly think about propaganda art and an attempt to form music by the apparatus of state supervision ${ }^{1}$ ), in many more cases the cultural and musical love affair begins in a conscious and intentional manner: one creates art (in this case - music) in order to preserve and to present a different, more global dimension of a given culture. An example of such art is furnished by World Music, which is extremely politicised.

However, even a different thing may be the case, artists may consciously embrace a different path and sever a maximum number of links with which culture entwines them (musical awareness, academic education, musical tastes, which were acquired in one's youth). Complete freedom of creating things out of sonic material and an attempt to break the cultural intermediation of music in cultural awareness is realised in the department of Sound Art.

Both areas of musical output may be compared not only on the plane of sound but also as a factor of the creation of the historical transformations of art, as well as the potential carriers of cultural content (it may determine the extent to which objective content of culture was included in a given form of creative output or not). For all researchers, for whom it is relevant to preserve diversity, and therefore, to a certain extent, cultural separations, the research method known as transculturalism ${ }^{2}$ may turn out to be relevant. This relatively recent area of research combines cultural studies and philosophy, and therefore it draws on empirical research in the phenomena of culture, and it enables an evaluative attitude toward the said phenomena. The latter are considered autonomous, relevant entities which also are subject to pro-

${ }^{1}$ Cf. P. Tendera, W. Rubiś, O wyzwoleniu sztuki od państwa [On the liberation of art from the state], pp. 115-122 (cf. [www 01] accessed on 12.11.2018).

2 Cf. P. Tendera, W. Rubiś, Global - Trans - Multi? Contemporary art in the lecture, pp. 64-69, (see more: [www 02] accessed on 12.11.2018). 
tection as axiologically valent elements. The transcultural method enables a reaction to the breaking of the continuity of culture and a free migration of cultural content in a globalised, uniform world. The purpose of transculturalism is to preserve the original content of various areas of culture along with their context, value (axiological system) and significance. In this sense, transculturalism opposes globalisation and multiculturalism ${ }^{3}$.

World Music is a good example of a peculiar cultural battle which is currently fought between popular (globalised) culture promoting World Music as the fruit of pacifist ideologies, and the actual history of the origin of the trend ${ }^{4}$. For many years, this concept was not understood properly also in Poland (testimony of which is furnished by erroneous translations of even the basic textbooks devoted to the history of jazz ${ }^{5}$ ), under this concept one understood the literal "music of the [whole] world" disregarding its definition, genre-related properties, also failing to verify its actual history (origin). Obviously, the reader intuitively felt the exoticism, the multiculturalism or a peculiar mixture of ethnic styles, although a description of this kind expanded the area of World Music to cover any kinds of music, making of it an esoteric sphere of sounds of global unification in the spirit of New Age or folk-ethnic music. However, the area of World Music is too old a phenomenon to associate it with any new epoch, for World Music arose in the $1960 s^{6}$.

In an ideological and historical sense, World Music is jazz returning to its roots - to African culture which was recalled by the descendants of slaves, but not only by them. World Music is also vocal opposition against the culture of whites, against Christianity and it is also the rebirth of the identity of national minorities - not always in the spirit of global unification, which is promoted today. It is rather that World Music opposes it. When we take all of these aspects into consideration, World Music demonstrates that ethnic and

3 Cf. P. Tendera, Cultural Phenomena Seen from the Perspective of Language Issues (Globalisation, Multiculturalism, Interculturalism and Transculturalism): Preliminary Reflections for Cultural Studies, pp. 179-191.

4 Many opinions indicate that the concept of World Music has been designed by entertainment music producers, which you can read about in: T. Brennan, World Music Does Not Exist, pp. $44^{-62 .}$

5 In my opinion, the translation of Joachim Berendt's book entitled Wszystko o jazzie calls for explanation; in the Polish translation of this 1991 work we read about the "incursion «of world music» to jazz". Further reading of the book indicates that what was meant was World Music. Cf. J. E. Berendt, Wszystko o jazzie. Od Nowego Orleanu do jazz-rocka, p. 41.

${ }^{6}$ Cf. J. E. Berendt, Wszystko o jazzie..., op. cit., p. 17. 
racial conflicts constitute a creative impulse in art. To a large extent, we "owe" the existence of jazz in its numerous iterations and in World Music itself to slavery; Sound Art cannot boast such a past and tradition. It is worthwhile to remember that $90 \%$ of slaves who were taken away from Africa originated from Cape Verde, Senegal, Togo, Benin, Nigeria, Cameroon or Congo. Therefore, slaves did not represent African culture by their tradition at all. Depending on their place of origin and the area to which they were deported (e.g. whether they were subject to Christianisation or whether they could practice their religion, the conditions of their life in slavery) they preserved other elements of their native culture. Such reconstruction of "musical geography" is the approach of an archivist: an approach which represents in-depthness, meticulousness which is peculiar to transcultural studies, which consist in the reconstruction of history in its material and spiritual traces. Such stories, and even legends similar to those associated with jazz and World Music, are completely irrelevant to the area of Sound Art. And legends and heroes associated with the history of slavery are legion...

It is sufficient to recall the figure of John Newton (1725-1807), a man who stayed at sea since the age of 11 , a man who was removed from the Royal Navy, a slaver, the author of more than 200 hymns, who converted due to being influenced by reading a book by Thomas À Kempis. Newton, who was moved by reading, let slaves go on the coast of Georgia, and he became a clergyman in Olney himself. He became famous owing to a brilliant composition known as Amazing Grace. The hymns that he authored were adopted in many currents of the revival camp meeting and other religious trends ${ }^{7}$. One may multiply examples of inspiration for jazz, World Music and the American tradition of religious music ad infinitum.

In British colonies psalms were sung which were brought by pilgrims and puritans who lived in New England; for them, lining out was a typical feature. All the brilliant musical forms were subsequently transformed as a result of reformed singing. The singing of Whites, the singing of Blacks, the Jazz of White people, and the Jazz of Black people - these were all different things. But when we direct our attention to this remote history we must remember that we are doing so owing to the unbroken thread of the cultural and musical development of the social groups of America who created World Music. We are doing so above all to emphasise very clearly that in contradistinction to the now-popularised concept of World Music as a thing which arose from the foundation of openness, diversity and tolerance toward other culture,

7 See: Z. F. Smith, The Great Revival of 18oo: The First Camp Meeting, pp. 19, 21-35. 
one must demonstrate that it is actually derived from the racial, and even racist movements of Black American people of the 1960.

Therefore, one should enumerate that the basis of World Music is associated first with the racial and national (the negro-trends) and the separatist and also socialist (sometimes communist) postulates of Black people. The area of World Music and rap (gangsta rap) saw the development of political movements of Blacks (e.g. the Black Panther Party and the influence of its founders, Huey P. Newton and Bobby Seale, on the creative output of a rapper who was popular in Poland, 2 Pac Shakur). Due to separatist sentiments, music saw a departure from intellectualism in favour of emotionalism, which was a result of the conviction about the musical superiority of the musical culture of Blacks, and the pursuit of new musical forms which were alternative to Western ones resulted in the drawing from foreign cultural traditions and the rejection of the "white" European cultural tradition in the style of playing, the choice of instruments, as well as religion and political views. These remarks may be enhanced by a philosophical and political thesis: Black people who represented separatist movements set the concept of solidarity above the typically American understanding of freedom.

One of the previously mentioned justifications for the emergence of World Music was the opposition of Black jazz musicians against modern European and English musical trends. Such tendencies arose in the jazz world of Black musicians after 1940, we may perceive this on the basis of the example of bebop, the renaissance of the New Orleans style, and the withdrawal of Black musicians from the reviving Dixieland. These movements manifested themselves inter alia in the wave of instances of conversion of Black jazz musicians to Islam and, for example, the associated change of names (e.g. Art Blakey called himself Abdullah Ibn Buhaina, and Ed Gregory called himself Sahib Shihab etc.). Generally speaking, in the 1940s, Black jazz musicians were committed to draw from non-European musical cultures, for example the Hindu/Indian (they were particularly fascinated by the rhythmical richness, the talas and the ragas), Japanese, African, Arabic music...

The postulates of Black musicians, from which World Music was subsequently to arise, also opposed the nascent, strongly intellectualising trends of free jazz, and their appeal to familiarisation of exotic musical cultures were also associated with a desire to tackle the emotional and religious potentialities of music. Black musicians frequently thought that the emotionality and the musicality of their race is considerably "greater" and "superior" than the 
emotionality and musicality of European and English musicians. Hence the origin of names with the negro- prefix/element (such as Negro spirituals ${ }^{8}$, negro minstrelsy, negro gospel swing) and the convictions, for example, that a Christian person cannot be a good jazzman.

Heretofore the thesis about the origin of World Music which was presented above was not unambiguously confirmed, although the particular historical analyses do perceive specific relationships, such as the clear relationship between the trends such as the Great Awakening (especially after 1970), the renewal of African culture, numerous instances of the conversion of distinguished jazz musicians to Islam and the origin of World Music.

Without doubt, today World Music is a different thing, therefore I also adduce a more popular definition according to which World Music is a trend of contemporary light music which is marked by references to traditional/ethnic music. World Music is music which features elements of jazz (swing, bebop, Latin), world fusion, global fusion, ethnic fusion, worldbeat, neo-traditional, it also features traditional elements such as the harp, drums, various types of compositions, polytonic and polyrhythmic systems from ethnic cultures, the regions of India, the Balkan Peninsula, the Iberian Peninsula (flamenco) and of the Roma (manouche) and Jewish people (Klezmer music), who are dispersed around the world, the elements of Tibetan chant, Japanese koto music, Hindu/Indian ragas. A considerable influence upon World Music was exerted and continues to be exerted by migration-related processes and the rapid development of technology. The history of World Music demonstrates how separatist activities engender more open artistic trends. All of these elements of World Music constitute valuable material for culture studies research, they also represent innovation, and, to a great extent, interdisciplinarianism. Moreover, as far as the important, historical aspects are concerned, they set World Music apart from (any) relations with Sound Art.

In the preceding remarks I defined World Music as a transcultural phenomenon. Now I should add a remark of methodological nature: phenomena of this kind do not occur spontaneously (as is the case as far as Sound Art

8 Cf. G. B. Johnson, The Negro Spiritual: A Problem in Anthropology, pp. 157-171 and in historical context: A. E. Clotheir, Two Negro Spirituals from Georgia, p. 98; A. E. Clotheir, Negro Spirituals from the Far South, pp. 223-249. 
is concerned) but by way of conscious cognitive-creative activity, and that transcultural art is not mass (globalised) art. However, it may be light art and it is sometimes high art. Let us remark that because identification/recognition of transcultural art requires cultural competence, by this fact transculturalism itself becomes an academic discipline. In World Music we emphasise that even though elements which are mixed with each other yield a new compositional and aesthetic quality, they are nevertheless identified as fragments borrowed from foreign cultures, which are identifiable. Transculturalism is the implantation of an element which is foreign in a culture, and it is also the preservation of this element in it. Therefore, what is important in transcultural art is the familiarity with the context, philosophy and frequently the history, which enable us to separate this foreign element, and, as a result, appreciate its presence aesthetically. Due to this, Word Music furnishes ample material for the development of a transcultural method in reference to artistic output and philosophy. Such possibilities are revealed not only by a historical and formal analysis of works in aesthetically varied exemplifications (mainstream jazz, swing, bebop, Latin, world fusion, global fusion, worldbeat, neo-tradition, the influences of Hindu/Indian, ethnic Arabic, Jewish, Roma, folk African and European music), but also universality which manifests itself in the creative process, improvisation and the peculiar nature of musical expression.

\section{$*$}

World Music is a phenomenon which was described for the first time in 1960 by Robert E. Brown, but it was adopted by the common discourse on art only in 1980 in a book by Ch. Nickson entitled The NPR Curious Listener's Guide to World Music (Grand Center Press, 2004). The circumstances of the emergence of World Music are also described by Timothy Rice, who recurrently points out that since 1987 the term World Music has been used as a term similar to ethno, but not as neo-traditional, not as mass art. It is worthwhile to emphasise clearly that this term was not completely assimilated with the musical tradition and milieu, many critics and musicians point out that the application of this term classifies the music of the world of many cultures by a uniform and not-always-accurate language of the Western globalising culture, one also points out the artificial origin of this concept (the so-called designed phenomenon). 
Word Music is a trend which is relatively rarely analysed in philosophical and culture studies publications. It is worthwhile to adduce articles which are devoted to the pedagogy of this type of music. Let us mention, by way of example, the work of Arnold B. Bieber entitled "Arranging World Music for Instrumentalists" 9 , in which we may find a few extremely apposite remarks concerning the teaching and the arrangement of music which represents World Music. Bieber analyses examples of exotic musical works, indicating the problematic points associated with the dissimilarity of scales, dynamics, instrumentation and musical expression. He also asks the question about the best method of teaching a non-Western type of music (the latter is a concept which is frequently applied in English-language publications). In other words, how does one introduce to the teaching curriculum such exotic instruments as the Indian sitar ${ }^{10}$, the Jamaican steel drum, or the Chinese instrument known as erhu, and also how does one teach students to perceive music played on these instruments, the tonal, rhythmic system, and the complex structures and principles of a given musical language. Bieber makes the following remarks:

"Having arranged works from China, Bali, Bolivia, and Central Africa for solo flute, percussion ensemble, concert band, and string orchestra, I can testify that creating such arrangements is challenging but feasible. Although such music may sound strange at first, students soon begin to hear its beauty and depth as they perform it. Moreover, simple guidelines can help directors create reasonably «authentic» world music arrangements for their students in band, orchestra, or other instrumental ensembles" ${ }^{11}$.

Bieber himself emphasises the intercultural essence of music. He points out that the practical classes which he conducts furnish an opportunity to expand the knowledge of students in the area of the religious, cultural, historical and philosophical context in which the relevant works arose. The point is to realise the social and geographical role which music plays in other cultures. The awareness of such dependencies influences the correct musical interpretation of a piece of music which is arranged. Bieber emphasises the following point: "Students should clearly understand that an arrangement of a piece of world music is not the same thing as an authentic performance by

9 A. B. Bieber, Arranging World Music for Instrumentalists, pp. 17-38, [www 03].

${ }^{10}$ Cf. P. van der Lee, Sitars and Bossas: World Music Influences, pp. 45-70.

${ }^{11}$ Ibidem, p. 17. 
indigenous musicians on indigenous instruments. Never attempt to represent it as such"12.

One of the more important artists who made a considerable contribution to the development of the current of World Music was Joe Zawinul (1932-2007), the creator of the famous artistic project known as the Zawinul Sindicate. This group used non-European musical and cultural elements, arranging the original works of a selected cultural area. Therefore, the idea consisted not only in the adaptation of the components of a foreign culture but also on the actual participation of the representatives of selected cultures in the creation of music (apart from people of African descent, there were also musicians from South America, India or Arab countries). Due to this, the whole endeavour was actually an intellectual and philosophical game. World Music created the tradition of contemporary popular and dance music of the world. A well-known representative of World Music is Richard Bona, who hails from Cameroon. This multi-instrumentalist and vocalist is the former member of the Pat Metheny Group (jazz, fusion) and the previously mentioned Zawinul Syndicate. Bona, even though he performs African music, did avail himself of Western education (he studied in France) and he is inspired by jazz (e.g. the creative output of Jaco Pastorius).

All of these activities demonstrate that transcultural music is realised to produce great aesthetic and artistic effects. However, it is worthwhile to point out that the maintenance of the Western melodics and harmony prompt the question about the limited originality and source-ness of these exotic particles. The instances of musical behaviour of other cultures which are expressed by means of traditional instruments such as e.g. the djembe, oud, sitar etc. also require an original (meta-) language, which consists of peculiar scales, the possibility of notation of sound and even an aesthetic theory. The creative output of World Music gained fans around the world and one may study it by means of cultural methodology, defining it as transcultural or intercultural, depending on how restrictive an attitude we are going to embrace in reference to the relation between a phenomenon and a concept that it is supposed to describe. This restrictiveness or freedom in the application of a concept is associated for example with the fact that it is extremely difficult to determine the extent to which one's Western (especially academic) music education permanently modifies the sonic layer in the creative output of a given artist, the extent to which the Western paradigm blocks a return

\footnotetext{
${ }^{12}$ Ibidem.
} 
to a native musical culture. We cannot determine the extent but we know that it is a fact.

The openness of the idea of World Music encourages one to engage in experiments. "Risky" endeavours at the meeting point of cultures emerge, such as Bach or Chopin "à la africaine" ${ }^{13}$. These projects constitute examples which inspire one to embrace musical openness, and at the same time they are thoroughly thought-out, non-random: the contribution of musicians who represent foreign cultures is not limited to the provision of mere ornament, it does not constitute an additional colour, but it constitutes a new, an authentic sonic value, transcending the European musical paradigm. Due to the study of World Music one could ask, in the zoth century, about the role of music in the intercultural and international understanding. I believe that to a great extent such studies are still ahead of us, for in the department of musical works there is a shortage of competent theoreticians who could engage the problem of transculturalism from the perspective of a musical language. It seems that in this context World Music is somehow at variance with the intentions of the artists who represent Sound Art. Therefore, let us now explore the fundamental differences.

\section{$*$}

According to what was stated above, World Music ${ }^{14}$ and Sound Art ${ }^{15}$ are concepts or phenomena which are placed in literature in similar cultural and visual contexts, but as far as their musical and content-related aspects are concerned, they differ considerably. A common cultural context is derived from the common question about the limits of language for the generally conceived contemporary music - a question which must be answered differently in both cases. However, a definition will remain open: the concepts of World Music and Sound Art are in a state of constant development, it is

${ }_{13}$ Cf. Lambarena - Bach to Africa (2009), [www 04] (accessed on 22.02.2016), cf. also: Chopin na 5 kontynentach [Chopin on five continents], an artistic project: [www 05] (accessed on 11.11.2018).

${ }^{14}$ According to Oxford Music Online, the birth of the World Music current falls to the 1970s1980 and it is associated with the popularity of ethno music in the United States. See the following for further information: Matthew J. Forss, World music, [www o6]. See also: B. Nettl, C. Capwell, P. V. Bohlman, I. K. F. Wong, and T. Turino, Excursions in World Music, and E. Wald, Global Minstrels: Voices of World Music.

${ }^{15}$ Cf. Mandy-Suzanne Wong, Sound art, [www 07]. 
difficult to speak about an established definition which could exhaust their semantic range.

World Music is creative activity at the meeting point of cultures, and this situation forces artists to exercise particular care about the quality of intercultural dialogue. It seems that such a set of problems does not exist in the department of Sound Art at all. A child of the neo-avant-garde, Sound Art is the broadly conceived (as broadly as possible) sonic activity, which was conceptually initiated by John Cage, who used the phrase "turn toward sound" which is familiar today. In this sense Sound Art is an expression of the rejection of the former thinking about music, about the manner of its creation, and as a result it is also an expression of the rejection of the fundamental construction elements of a work, such as melody, harmony or rhythm. But can Sound Art be treated like a product of a specific culture? Can one perceive inspiration by some foreign cultures in it?

The phenomenon of Sound Art is broad and it consists of many activities. Currently, we speak about the concept of Sound Art itself in art which focuses on the creative and aesthetic potential of combining various media: sounds, installations, space, kinetics, performance. The sources of thinking about Sound Art constitute the discoveries and the problems which were put forward by the composers of the second half of the zoth century, such as Edgar Varèse and John Cage. They claimed that the traditional manner of thinking about musical material severely limits creativity. The broadening of the field of activity of the composer may consist in an attempt at abolishing or at least limiting the authority of the Western musical paradigm. However, these are not the musical questions which were relevant to the artists who represent World Music - as far as the philosophical aspects are concerned, World Music is a philosophy of culture which as a result acquires its peculiar musical sound, Sound Art is a philosophy of sound, an ontology of sound, whose analysis of a musical work is limited to the significance of one subject - sound. In the case of Sound Art, sound is abstracted from the cultural foundation, which does not mean that the particular artists are not inspired in their activities by some type of extra-musical philosophical thinking.

In the case of artists who represent World Music, the limitations associated with the European musical tradition led to other musical solutions/ decisions. The artists who represent Sound Art aptly observed that if we use the definition of music consistent with the European tradition, it is difficult to refer to the musical activities of non-European cultures as music at 
all, despite the fact that we are doubtlessly dealing with intentional soundrelated activities in them. Indeed, few cultures replicate our principles of music: these cultures are, for example, surprisingly primitive, if we compare them according to the European paradigm. Europe, in comparison with these cultures, developed e.g. melodics in an extremely intricate manner, the major/minor system, the equal temperament, functional harmony etc. What results would we acquire, if we compared the Wagnerian melodics and traditional African songs, where music to this day is based on the pentatonic scale, sometimes it uses a triad, and the fundamental part is played by rhythmisations/polyrythms by taking the European musical paradigm as the basis for comparison?

In the observation of the problems which were indicated above, the previously mentioned Edgar Varèse stated that if we intend to find a new definition of music which would cover all sound-related activities, we should realise that music is above all organisation of sounds ${ }^{16}$. This statement was supplemented by Cage, who added that the thing which is relevant in music constitutes the sounds - absolutely all audible sounds ${ }^{17}$. For artists who represent Sound Art who draw inspiration from these words, the essence of music is constituted by sound, by sound alone/itself, which is the object intended for listening.

Such a premise force the researcher to change the perspective of perceiving music from pursuing musical structures and harmony (order) to the processuality of listening and the existence of sound. However, this processuality is different from the processuality which was put forward by Roman Ingarden or Zofia Lissa, because it does not constitute a coherent utterance/expression/statement. It is rather a sequence of sounds between which a structure does not have to develop. Placing emphasis on processuality may be found also in jazz, but here a significant role is played by narration and story-telling, interaction in improvisation and harmony. Therefore, one may clearly see that in the case of Sound Art processuality refers not to musical structures but to their components (sounds) and it has a very peculiar, characteristic meaning/significance.

In Sound Art it is important how we listen and not the thing that we listen to. This would be a sort of "a new paradigm in music", which was referred

${ }^{16}$ E. Varèse, The liberation of Sound, in: Audio Culture, Readings in Modern Music, ed. Cox \& Warren, NY 2006, p. 17-21.

${ }^{17}$ J. Cage, The Future of Music: Credo, pp. 25-28. 
to by Michael Nyman as "experimental music" 18 . In the introduction to his book which bears the same title we may find a significant statement of Brian Eno: “...we concluded that music didn't have to have rhythms, melodies, harmonies, structures, even notes, that it didn't have to involve instruments, musicians and special venues. It was accepted that music was not something intrinsic to certain arrangements of things - to certain ways of organizing sounds - but was actually a process of apprehending that we, as listeners, could choose to conduct. [...] If there is a lasting message from experimental music, it's this: music is something your mind does"19.

Therefore in the space of Sound Art new sound-related events and situations arise, in which composers disappear, and sounds do not have to be intentionally and consciously ordered but they may be produced automatically, randomly or intuitively, and actually in any way whatsoever. In the case of jazz and improvisation (and especially in the case of free jazz) we will encounter a proposition to refrain from pursuing musical structures; the sequence of sounds will reveal itself before us in due time. But in Sound Art the case is different - we should learn to refrain from pursuing the said structures because we will not find them - they are not there.

Teachers of World Music debate about the correct manner of notation of music, so that the student of a Western university knows not only the extent of the sonic possibilities of an exotic instrument but he or she will also know how to represent non-European musical practices in notation ${ }^{20}$. This is a real problem because in a restrictive sense the reconciliation of exotic music with the Western musical parading is impossible ${ }^{21}$, the European notation is severely limiting in this context, it is adapted to those sonic activities which we ourselves consider relevant. Even so, systematic research is conducted

${ }^{18}$ Cf. M. Nyman, Experimental Music: Cage and Beyond, and Ch. Ballantine, Towards an Aesthetic of Experimental Music, pp. 224-246, cf. also: R. Smalley, Experimental Music, pp. 23-26. See also: C. Sun, Experimental music, [www 08].

${ }^{19}$ M. Nyman, Experimental Music: Cage and Beyond, p. xii.

${ }^{20}$ Cf. Chee-Hoo Lum, Teaching World Music through Feature Films, pp. 71-75, or: W. Schmidt, World Music in the Instrumental Program, pp. 41-45 (many articles available on the Internet present the specificity of teaching World Music in individual cultural and academic centers).

${ }^{21}$ Cf. A. B. Bieber, Arranging World Music for Instrumentalists, pp. 17-20, 38, (see: [www 03]). 
whose purpose is to develop translation which would be as accurate as possible. Meanwhile in the case of research in Sound Art, the object of analysis is constituted by musical activities which respect Cage's postulate associated with treating sound as sound. The research of this kind of musical output does not consist in an analysis of its tradition or correctness because Sound Art clearly disassociates itself from traditional forms and in this context it is pre-eminently anti-traditional.

This peculiar simplification of the historical background in the department of Sound Art is made up for by a creative combination of audial elements with other sources of sensory stimuli: kinetics, light, image, movement etc. Moreover, in Sound Art, the principle or the tradition of instrumentalistics loses its relevance - it also becomes an entirely random concern. The rejection of the harmonic paradigm of Europe also results in the rejection of its instrumentalistics. The development of Sound Art or experimental music is associated with a pursuit of new sources of sound, the development of electronic instruments, the application of "extramusical" ambient sounds as the material of sonic art, or finally with the sound emission and editing computer software, which continues to improve. In sonic activities in which traditionally conceived melody and harmony are not relevant construction factors, one does not pursue virtuosity as far as playing musical instruments is concerned, therefore the department of instrumentalistics, understood as a part of performance, gradually declines.

It is worthwhile to add that as in the case of the remaining trends of experimental music, which was developed after the "Cage revolution" we are dealing with a postulate to listen to new (modern?) things, which is the basis for the perception of music understood according to the traditional European paradigm (including also the following: the concept of aesthetic listening of Hanslick ${ }^{22}$ and the concept of structural listening of Subotnik ${ }^{23}$ ). The concept of listening is associated with certain activities of Sound Art is similar to that of affective listening, which was proposed by Wang Jing ${ }^{24}$. It consists in listening to sounds and not in the reading out and recognising cultural codes inscribed in sonic structures; listening open to sound, without

${ }^{22}$ For further information see: E. Hanslick, On the Musically Beautiful: A Contribution towards the Revision of the Aesthetics of Music.

${ }^{23}$ For further information see: R. R. Subotnik, Deconstructive Variations, Music and Reason in Western Society.

${ }^{24} \mathrm{~J}$. Wang, AFFECTIVE LISTENING: China's Experimental Music and Sound Art Practice, [www 09]. 
the function of reading and decoding, consisting in the perception of soundrelated phenomena as such, (in prospect) without intellectual "processing". Often, we are dealing with psychophysical - in the literal sense - perception of acoustic waves - in this there also lies a significant change in the perception of an aesthetic experience as a (potentially, in prospect) purely sensory one.

A separate problem has to do with the intentionality of sonic activities in Sound Art, which results from the indispensable presence of a creator/artist (the subject). Even though the artist is present, by placing emphasis on the priority of listening, the centre of gravity is shifted toward the sonic process, which arises not as purposeful order but as order which reveals itself, which is emergent, which is also an enigma for the creator himself. The sense of activity of this type lies in the experience of sound emitted in real time, for example in the atmosphere of a music concert or in an initiated "sonic situation". The realisation of this perspective of reception changes the perception of the spectator and enables the establishment of a completely new relation (quality-wise) between performing musicians and spectators ${ }^{25}$.

A similar manner of the treatment of the audiosphere became the foundation of soundscapes, which emerges on the basis of the postulate of the equality/emancipation of all sounds as music material. Each sound, treated separately/individually, as a unique sonic entity, is important. A method of listening which abandons the analysis of structures and focuses on each individual sound - a method in which each sound is relevant as a sound - must be associated with such a practice.

\section{Concluding remarks}

Traditional musical education may prove a hindrance in the complete utilisation of the resources of both World Music and Sound Art. However, this is the case because of two different reasons. World Music is a cultural challenge; it requires knowledge derived from the area of other cultures, knowledge which refers to values, religious affiliations, beliefs, purposes of art, significance of music, language, instruments and practice. Sound Art also constitutes an opposition to the traditional Western musical education because it

${ }_{25}$ Cf. A. B. Bieber, Arranging World Music for Instrumentalists, pp. 17-20, 38, March 1999 (see: [www 03]). 
is an alternative conceptual and philosophical endeavour - it is a new, pure philosophy of sound, its ontology.

During the "processing" which the mind undergoes during the process of academic musical training the structures of listening to and thinking about sound and working with sound are "imprinted" into the mind. It is difficult to liberate oneself from those structures. What is important, these differences also refer to the very foundations which refer to the strategy of action in musical practice. When the traditional paradigm, to oversimplify things, consists in the creation of structures by means of the so-called purposeful/intentional order, in the case of free improvisation, we are sometimes dealing with the so-called spontaneous order which reveals itself.

Despite this freedom and escape from tradition in Sound Art we are speaking about aesthetic qualities and values. The ambient sounds, the audiosphere are the object of aesthetic reception, just as the sounds which are emitted by instrumentalists. Indeed, in the new manner of listening there is no division into traditionally understood musical and extra-musical sounds. All acoustic sounds are (or they at least may) become the object of aesthetic perception: either the sounds of instruments, emitted by means of traditional or extended performance resources, the sounds of nature, the sounds of traffic. For Sound Art each sound constitutes a separate object of aesthetic experience. Therefore, one cannot confuse this aesthetics with "aesthetic listening", which was discussed by Hanslick - for the latter the aestheticness consisted in the listening to the intentions and the recognition of the composer's intention. Such a typology of listening is "aristocratic" and elitist, it demands specialist knowledge on the part of the recipient. If the recipient does not have such knowledge, he or she "listens in a pathological" or "passive" way, which signifies passive perception of sounds. For Sound Art it is the simple, sensory (visceral), experience of music that is the most important thing.

The audiocentric turn in culture, which is doubtlessly associated with the neo-avant-garde breakthrough, covers the areas of both pop culture and "high" culture. Increasingly numerous instances of sound studies gain relevance, also new instruments of musical analysis, which are associated with the increase of the significance of hearing in reference to seeing, appear. New developments in this area are also featured in such well-established disciplines as the academic theory of music.

When we write about World Music and Sound Art we engage separate departments - not only creative but also philosophical ones, which do not 
meet each other also in the context of cultural studies, even though both phenomena constitute a manifestation of the changes in the 2oth-century musical culture. World Music and Sound Art are two separate concepts, they also emerged at various periods of the development of music: World Music and jazz, light music, ethno-jazz, refer to the paradigm which was exclusively binding in Europe until the middle of the zoth century. Along with the neoavant-garde a breakthrough occurred, which is currently associated with the audiocentric turn. Many contemporary artists who represent electronic and improvised music do not have institutional musical education, therefore in many cases they do not have an opportunity to familiarise themselves with the traditional musical paradigm. Hence, the artists who represent Sound Art create works which fall under the category of experimental music.

\section{Bibliography}

1. Ballantine Ch., Towards an Aesthetic of Experimental Music, "The Musical Quarterly", Vol. 63, No. 2 (Apr., 1977), pp. 224-246.

2. Berendt J. E. , Wszystko o jazzie. Od Nowego Orleanu do jazz-rocka, S. Haraschin, I. Panek (tłum.), PWM 1991.

3. Bieber A. B., Arranging World Music for Instrumentalists, "Music Educators Journal”, vol. 85, no. 5, pp. 17-20, 38, March 1999, [www 03].

4. Brennan T., World Music Does Not Exist, "Discourse", Vol. 23, No. 1, Imperial Disclosures: Part II (Winter 2001), pp. 44-62.

5. Chopin na 5 kontynentach [Chopin on five continents], an artistic project: [www 05] (accessed on 11.11.2018).

6. Clotheir A. E., Two Negro Spirituals from Georgia, "The Journal of American Folklore", Vol. 55, No. 215/216 (Jan. - Jun., 1942).

7. Clotheir A. E., Negro Spirituals from the Far South, "The Journal of American Folklore", Vol. 35, No. 137 (Jul. - Sep., 1922), pp. 223-249.

8. Forss M. J., World music, "Grove Music Online. Oxford Music Online", Oxford University Press. Web. 21 Feb. 2016, [www 06].

9. Hanslick E., On the Musically Beautiful: A Contribution towards the Revision of the Aesthetics of Music, Hackett Publishing Company, Indianapolis 1986.

10. Johnson G. B., The Negro Spiritual: A Problem in Anthropology, "American Anthropologist”, New Series, Vol. 33, No. 2 (Apr. - Jun., 1931), pp. 157-171. 
11. Lambarena - Bach to Africa (2009), [www 04] (accessed on 22.02.2016).

12. Lum C.-H., Teaching World Music through Feature Films, "Music Educators Journal", Vol. 95, No 3 (Mar., 2009), pp. 71-75.

13. Nettl B., Capwell C., Bohlman P. V., Wong I. K. F., and Turino T., Excursions in World Music, Upper Saddle River, NJ, 1992, 2/1997.

14. Nyman M., Experimental Music: Cage and Beyond, New York, G. Schirmer Inc., 1974.

15. Nyman M., Experimental Music: Cage and Beyond, Cambridge 1999.

16. Schmidt W., World Music in the Instrumental Program, "Music Educators Journal”, Vol. 78, No. 9, Special Focus: Multicultural Music Education (May, 1992), pp. 41-45.

17. Smalley R., Experimental Music, "The Musical Times”, Vol. 116, No. 1583 (Jan., 1975), pp. 23-26.

18. Sмiтн Z. F., The Great Revival of 18oo: The First Camp Meeting, "Register of Kentucky State Historical Society”, Vol. 7, No. 20 (May, 1909), pp. 19, 21-35.

19. Subotnik R. R., Deconstructive Variations, Music and Reason in Western Society, University of Minnesota Press, Minneapolis/London 1996.

20. Sun C., Experimental music, "Grove Music Online. Oxford Music Online”, Oxford University Press. Web. 22 Feb. 2016, [www 08].

21. Tendera P., Cultural Phenomena Seen from the Perspective of Language Issues (Globalisation, Multiculturalism, Interculturalism and Transculturalism): Preliminary Reflections for Cultural Studies, "The Polish Journal of the Arts and Culture", No 16 (4/2015), pp. 179-191.

22. Tendera P., Rubiś W., Global - Trans - Multi? Contemporary art in the lecture, "International Journal of Teaching and Education", Vol. III, No. 1/2015, pp. 64-69, DOI: 10.20472/TE.2015·3.1.005, [www 02] (accessed on 12.11.2018).

23. Tendera P., Rubiś W., O wyzwoleniu sztuki od państwa [On the liberation of art from the state], "Zeszyty Naukowe Towarzystwa Doktorantów UJ. Nauki Humanistyczne”, No. 15 (4/2016), pp. 115-122 (cf. [www 01] accessed on 12.11.2018).

24. VAN DeR Lee P., Sitars and Bossas: World Music Influences, "Popular Music", Vol. 17, No. 1 (Jan., 1998), pp. 45-70.

25. Wald E., Global Minstrels: Voices of World Music, New York, 2007.

26. WANG J., AFFECTIVE LISTENING: China's Experimental Music and Sound Art Practice, "Journal of Sonic Studies" 2, [www 09]. 
27. Wong M.-S., Sound art, "Grove Music Online. Oxford Music Online", Oxford University Press, Web. 21 Feb. 2016, [www 07].

28. VArÈse E., The liberation of Sound [in:] Audio Culture, Readings in Modern Music, ed. Cox \& Warren, NY 2006, p. 17-21.

\section{Internet sources utilised:}

[www 01] https://ruj.uj.edu.pl/xmlui/bitstream/handle/item/38705/tendera rubis_o_wyzwoleniu_sztuki_od_panstwa_2016.pdf?sequence $=1 \&$ isAllowed $=y$ [www 02] http://www.iises.net/international-journal-of-teaching-education/ publication-detail-86

[www 03] http://www.jstor.org/stable/3399542

[www 04 ] http://www.allmusic.com/album/lambarena-bach-to-africa-mwoo 01878328

[www 05] https://culture.pl/pl/artykul/i-like-chopin-czyli-grajac-szopenatroche-inaczej

[www 06] http://www.oxfordmusiconline.com/subscriber/article/grove/ music/A2259436

[www 07] http://www.oxfordmusiconline.com/subscriber/article/grove/ music/A2219538

[www 08] http://www.oxfordmusiconline.com/subscriber/article/grove/ music/A2224296

[www 09] http://journal.sonicstudies.org/cgi/t/text/text-idx?c=sonic;sid= 29cbb5e8bf131132de65edad24fa1530; view=text;idno=mo2o1a11;rgn=main 